\title{
Reverse Zymmogram Analysis for the Detection of Protease Inhibitor Activity \\ Lilia Bernal ${ }^{\#}$, Florencia García-Campusano ${ }^{\#}$, Edgar Nájera and Felipe Cruz-García*
}

Departamento de Bioquímica, Universidad Nacional Autónoma de México, Mexico City, Mexico *For correspondence: fcg@unam.mx

\#These authors contributed equally to this work.

[Abstract] This protocol describes a gel-based procedure to detect protease inhibitor activity. In this method gelatin is used as a substrate for proteolysis and is copolymerized within the polyacrylamide matrix. Protein extracts are fractioned by SDS-PAGE and then the gel is treated with the protease of interest, which degrades gelatin, except in the areas where inhibitory activity is present. Inhibition of protease activity appears as colored bands against a clear background after staining with Coomassie Brilliant Blue (Figure 1). The effectiveness of the assay is dependent on the capacity of the protease inhibitor to refold after SDS-PAGE fractionation. Alternatively, it can be performed using native (PAGE) gels. Although the protocol presented here has been standardized to test for subtilisin inhibitory activity, it can easily be adapted to test other proteases and protease inhibitors.

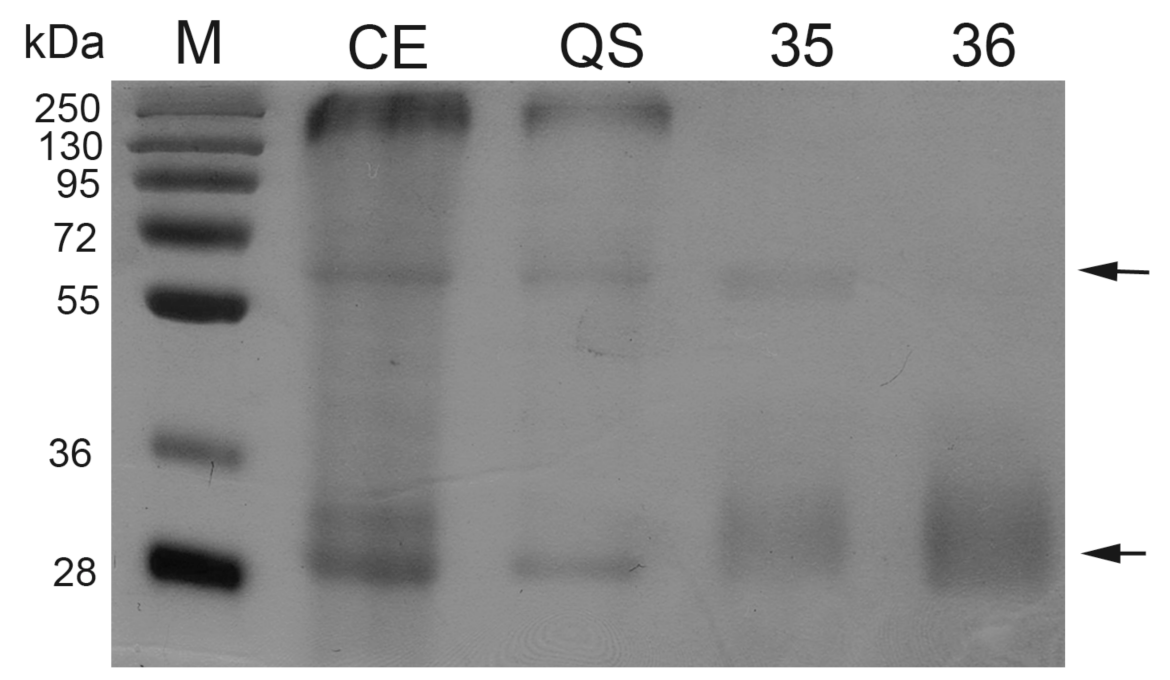

Figure 1. Protease inhibitor activity by zymogram analysis of different purified fractions and a protein crude extract. Zymogram was performed after SDS-PAGE. One microgram of protein was loaded to each lane. CE: Crude extract; QS: Fraction from anion exchange chromatography (Q-sepharose); Fractions 35-36: Obtained after a size exclusion chromatography (Superdex 200). M: Molecular markers. Arrows indicate inhibition activity. 


\section{Materials and Reagents}

1. Protein extract or purified protein $(1-5 \mu \mathrm{g})$

2. Aprotinin (Sigma-Aldrich, catalog number: A-3886)

3. Subtilisin (Sigma-Aldrich, catalog number: P-5380)

4. $30 \%$ Acrylamide stock (29:1 acrylamide:bisacrylamide) (Bio-Rad Laboratories)

5. TEMED (Sigma-Aldrich)

6. Ammonium persulfate (Bio-Rad Laboratories)

7. SDS (Bio-Rad Laboratories)

8. Tris base (Sigma-Aldrich)

9. Gelatin (Sigma-Aldrich)

10. Bromophenol Blue (Sigma-Aldrich)

11. $\beta$-mercaptoethanol (Sigma-Aldrich)

12. Glycine (Sigma-Aldrich)

13. EDTA (JT Baker)

14. Glycerol (JT Baker)

15. Pre-stain Protein Standard (Bio-Rad Laboratories)

16. Coomassie blue G250 (Sigma-Aldrich)

17. Ethanol (JT Baker)

18. Phosphoric acid (Sigma-Aldrich)

19. Triton X-100 (Sigma-Aldrich)

20. Separating gel buffer (8x) (see Recipes)

21. Stacking gel buffer (4x) (see Recipes)

22. Gelatin-SDS-PAGE Separating gel (see Recipes)

23. Stacking gel (see Recipes)

24. Sample loading buffer (see Recipes)

25. Laemmli Reservoir buffer (see Recipes)

26. Stain solution (4 L) (see Recipes)

\section{Equipment}

1. Protein mini gel cassettes (Bio-Rad Laboratories)

2. Power supply

3. Orbital shaker

4. Incubator 


\section{Procedure}

1. Preparation of the gelatin-SDS-PAGE gel

a. Clean and completely dry glass plates, combs, spacers $(0.75-1 \mathrm{~mm})$, and assemble the gel cassette.

b. Dissolve $1 \%$ gelatin in $\mathrm{dH}_{2} \mathrm{O}$ by heating, and keep warm to avoid gelling.

c. Prepare the $12.5 \%$ separating gel, replacing the corresponding volume of water with the gelatin solution to a final concentration of $0.1 \%$. Mix well and quickly transfer to the casting chamber to avoid the uneven gelling of the gelatin. Add a small layer of water or isopropanol prior to polymerization to level the gel.

d. Once the gel has polymerized remove the water or isopropanol layer and dry off as much as possible by using a filter paper. Prepare and pour the stacking solution into the casting chamber and insert the comb.

e. Sample Preparation.

f. Add the same volume of $2 x$ protein sample loading buffer to each protein extract to be tested, and mix. Do not heat at any time.

g. Use a protein-based protease inhibitor as a positive control for the reaction, such as: aprotinin for subtilisin, or trypsin inhibitor for trypsin and load it at a similar concentration to the protein samples tested.

2. Electrophoresis. Performed at $100 \mathrm{~V}$ for approximately $2.5 \mathrm{~h}$ at $4{ }^{\circ} \mathrm{C}$.

3. Eliminating SDS from the gel. SDS in the gel may interfere with activity of the protease inhibitor to be tested, so it must be removed from gel before treating the gel with the protease. Removal is carried out by:

a. Rinsing twice with $30 \mathrm{ml}$ of $2.5 \%(\mathrm{v} / \mathrm{v})$ Triton $\mathrm{X}-100$ solution, for $10 \mathrm{~min}$ each with agitation.

b. Rinsing twice with $30 \mathrm{ml}$ of $2.5 \%(\mathrm{v} / \mathrm{v})$ Triton $\mathrm{X}-100+50 \mathrm{mM}$ Tris- $\mathrm{HCl}(\mathrm{pH} 7.4)$ solution, for 10 min each with agitation.

c. Rinsing with $30 \mathrm{ml}$ of $50 \mathrm{mM}$ Tris- $\mathrm{HCl}(\mathrm{pH} 7.4)$, for 10 min with agitation.

4. For protein digestion, incubate the gel for $2 \mathrm{~h}$ at $37^{\circ} \mathrm{C}$, in a buffer solution containing 1.4 $\mathrm{U}$ of subtilisin in $50 \mathrm{ml}$ of $50 \mathrm{mM}$ Tris- $\mathrm{HCl}(\mathrm{pH} 7.4), 200 \mathrm{mM} \mathrm{NaCl}$.

5. For fixation, place the gel in a 10\% methanol, $10 \%$ acetic acid solution with gentle shaking for $30 \mathrm{~min}$. Discard the solution.

6. Detection of proteolysis inhibitors. Stain the gel with Coomassie Brilliant Blue, by adding approximately $100 \mathrm{ml}$ of stain solution and leaving it in an orbital shaker overnight. Discard the stain and rinse the gel with water until the background gel becomes clear, which indicates the efficient degradation of the copolymerized gelatin. The presence of 
stained bands indicates areas where gelatin was protected from degradation by the activity of a protease inhibitor (hence "protection bands").

7. Commonly a twin gel, lacking gelatin is run in parallel as a control.

8. If an antibody for the tested protease inhibitor is available, the digested gel can be transferred and an immunoblot assay can be performed.

\section{$\underline{\text { Recipes }}$}

1. Separating gel buffer (8x)

$3 \mathrm{M}$ Tris- $\mathrm{HCl}(\mathrm{pH} 8.8)$

2. Stacking gel buffer (4x)

$0.5 \mathrm{M}$ Tris- $\mathrm{HCl}(\mathrm{pH} 6.8)$

3. Gelatin-SDS-PAGE Separating gel

Add the following solutions (total volume: $5 \mathrm{ml}$ )

$30 \%$ acrylamide/bisacrylamide

$2.08 \mathrm{ml}$

$\mathrm{dH}_{2} \mathrm{O}$

$1.72 \mathrm{ml}$

Separating gel buffer (8x)

$0.625 \mathrm{ml}$

$20 \%$ SDS

$25 \mu \mathrm{l}$

$1 \%$ gelatin solution

$0.5 \mathrm{ml}$

$10 \%$ ammonium persulfate

$25 \mu \mathrm{l}$

TEMED (add it right before pouring the gel) $5 \mu \mathrm{l}$

4. Stacking gel (total volume: $2.5 \mathrm{ml}$ )

$30 \%$ acrylamide/bisacrylamide

$0.5 \mathrm{ml}$

$\mathrm{dH}_{2} \mathrm{O}$

$1.375 \mathrm{ml}$

Stacking gel buffer (4x)

$0.625 \mathrm{ml}$

$20 \%(w / v)$ SDS

$15 \mu \mathrm{l}$

$10 \%$ ammonium persulfate

$15 \mu \mathrm{l}$

TEMED

$5 \mu \mathrm{l}$

5. Sample loading buffer

$0.12 \mathrm{M}$ Tris

10\% 2-mercaptoethanol

$20 \%$ (v/v) glycerol

$2 \mathrm{mg} / \mathrm{ml}$ Bromphenol blue

6. Laemmli Reservoir buffer

$25 \mathrm{mM}$ Tris base

0.192 M Glycine

$0.1 \%(w / v)$ SDS 
$\mathrm{pH}$ around 8.3

Should not require adjustment

Store at room temperature

7. Stain solution (4 L)

Coomassie blue R250

$3.2 \mathrm{~g}$

Ethanol

$800 \mathrm{ml}$

Phosphoric acid

$64 \mathrm{ml}$

Ammonium sulphate

$320 \mathrm{~g}$

Dissolve Coomassie blue G250 in ethanol and add phosphoric acid. Dissolve the ammonium sulphate in water and add to the mix. Adjust final volume with water.

\section{Acknowledgments}

This protocol is adapted from Jimenez-Duran et al. (2013).

\section{References}

1. Jimenez-Duran, K., McClure, B., Garcia-Campusano, F., Rodriguez-Sotres, R., Cisneros, J., Busot, G. and Cruz-Garcia, F. (2013). NaStEP: a proteinase inhibitor essential to selfincompatibility and a positive regulator of HT-B stability in Nicotiana alata pollen tubes. Plant Physiol 161(1): 97-107.

2. Laemmli, U. K. (1970). Cleavage of structural proteins during the assembly of the head of bacteriophage T4. Nature 227(5259): 680-685.

3. Lantz, M. S. and Ciborowski, P. (1994). Zymographic techniques for detection and characterization of microbial proteases. Methods Enzymol 235: 563-594. 